\title{
Spectroelectrochemistry of Enargite I: Reactivity in Alkaline Solutions
} \author{
R.N. Gow ${ }^{1}, \mathrm{C}_{\text {Young }}{ }^{1}, \mathrm{H}_{\text {Huang }}{ }^{1}$, G Hope ${ }^{2}$, Y Takasaki ${ }^{3}$
${ }^{1}$ Montana Tech of The University of Montana; 1300 W. Park; Butte, MT, 59701, USA
${ }^{2}$ Griffith University; 170 Kessels Road, Nathan, Qld, Australia, 4111 \\ ${ }^{3}$ Akita University; 1-1 Tegata Gakuen-machi, Akita City, Akita P, Japan 010-8502
}

\begin{abstract}
Keywords: Enargite, Arsenic, Raman spectroscopy, Cyclic voltammetry, StabCal, Massbalanced $\mathrm{E}_{\mathrm{H}} \mathrm{pH}$ Diagrams
\end{abstract}

\begin{abstract}
The presence of enargite $\left(\mathrm{Cu}_{3} \mathrm{AsS}_{4}\right)$ is problematic in gold processing because it is environmentally hazardous due to its arsenic content but also because it is refractory, causing both cyanide and oxygen consumption to increase. Selective leaching and treatment of the arsenic would prove advantageous prior to applying conventional gold leaching methods. The reactivity of enargite samples from Butte, Montana and Quiruvilca, Peru were spectroelectrochemically studied under alkaline conditions, $\mathrm{pH}$ range of 8-13, using Raman spectroscopy and cyclic voltammetry. Raman spectra of the surface were collected during and after voltammograms were potentially cycled in order to determine and compare surface species against theoretical $\mathrm{E}_{\mathrm{H}}-\mathrm{pH}$ diagrams determined from mass-balanced thermodynamic calculations using StabCal software. Under slightly oxidizing conditions, covellite $(\mathrm{CuS})$ peaks were found in a short matter of time, above $\sim 100 \mathrm{mV}$ vs SHE for $\mathrm{pH} 9-13$, suggesting arsenic leaching specifically occurred. At longer conditioning times, elemental sulfur was observed and tended to passivate the surface. The presence of elemental sulfur suggests that copper was eventually leached from the surface. By operating above $\mathrm{pH} \mathrm{12,} \mathrm{under} \mathrm{slightly} \mathrm{reducing} \mathrm{conditions} \mathrm{near} \mathrm{-}$ $300 \mathrm{mV}$ vs SHE, arsenic can be selectively leached as thioarsenate $\left(\mathrm{AsS}_{4}{ }^{3-}\right)$ or thiosulfate $\left(\mathrm{AsO}_{4}{ }^{3-}\right)$ without sulfur formation.
\end{abstract}

\section{Introduction}

Environmental limitations on pyrometallurgical processing of ores and concentrates bearing arsenic and other hazardous elements often outweigh those in hydrometallurgical processing, particularly when minerals like enargite $\left(\mathrm{Cu}_{3} \mathrm{AsS}_{4}\right)$ are present. Hydrometallurgical processing of enargite-bearing materials can be broken down into two categories: the co-dissolution of arsenic and copper under acidic conditions and the selective leaching of arsenic under alkaline conditions. The selective leaching of arsenic would preferably leave behind copper-rich sulfide phases, typically chalcocite $\left(\mathrm{Cu}_{2} \mathrm{~S}\right)$ and covellite $(\mathrm{CuS})$, which then become more amenable to conventional copper (and gold) processing. Furthermore, selective leaching often employs sulfide $\left(\mathrm{S}^{2-}\right)$, bisulfide $\left(\mathrm{HS}^{-}\right)$or polysulfides $\left(\mathrm{S}_{\mathrm{x}}{ }^{2-}\right)$ to first extract the arsenic as $\mathrm{AsS}_{4}{ }^{3-}$ and $\mathrm{AsS}_{3}{ }^{3-}$ (Delfini et al., 2003; Anderson and Twidwell, 2008; Tongamp et al., 2010a,b). However, hypochlorite leaching (Viñals et al., 2003; Curreli et al., 2005; Mihajlovic et al., 2007), ammoniacal leaching (Gajam and Raghavan, 1983), and fine-grinding to mechanically activate the enargite surface (Balaz and Achimovicova, 2006) have been investigated to increase the normally slow reaction kinetics. Because gold ores are becoming more refractory due to increasing arsenic contents as a result of enargite, these methods are being examined more closely by the gold-mining industry. 
In this study, Raman spectroscopy and cyclic voltammetry were used simultaneously to look at surface reactions of enargite electrodes under alkaline conditions. Specifically, for this study, a spectroelectrochemical technique was used at $\mathrm{pH}$ 8-13 with potentials cycled between approximately -1000 and $+1000 \mathrm{mV}$ vs SHE. Precise control of these conditions along with various species concentrations will help in understanding how enargite behaves in solution as well as developing a hydrometallurgical separation process. It must be noted that this is the first in a series of three papers. The second paper (Gow et al. 2014a) covers results obtained under acidic conditions and the third (Gow et al. 2014b) examines alkaline sulfide leaching as one of the more favorable aforementioned hydrometallurgical processes.

\section{Thermodynamics}

A database of standard free energies of formation of species in the $\mathrm{Cu}-\mathrm{As}-\mathrm{S}-\mathrm{H}_{2} \mathrm{O}$ system has been compiled primarily using the MINTEQA2 (Allison, 1991) database but partially supplemented from other sources including the U.S. Geological Survey (Robie, 1984). Results are presented in Table 1. According to Craig and Barton (1973), there are five Cu-As-S sulfosalts; however, only enargite, sinnerite $\left(\mathrm{Cu}_{6} \mathrm{As}_{4} \mathrm{~S}_{9}\right)$ and tennantite $\left(\mathrm{Cu}_{12} \mathrm{As}_{4} \mathrm{~S}_{13}\right)$ have listed free energies as also presented in Table 1. They were calculated from the formation equations compiled by Craig and Barton (1973) based on gaseous sulfur $\left(\mathrm{S}_{2(\mathrm{~g})}\right)$ but converted herein to base them on elemental sulfur $\left(\mathrm{S}_{(\mathrm{s})}\right)$. It is noted that lautite $(\mathrm{CuAsS})$ and luzonite $\left(\mathrm{Cu}_{3} \mathrm{AsS}_{4}\right)$ are the other two $\mathrm{Cu}$-As-S sulfosalts but their free energies are unknown (Craig and Barton, 1973). Because enargite and luzonite have the same chemical formula, they have different crystal structures and are referred to as dimorphs. Additional solids for the system have also been identified including $\mathrm{Cu}\left(\mathrm{AsO}_{2}\right)_{2}$ (Nishimura et al. 1993), $\mathrm{H}_{3} \mathrm{AsSO}_{2}(\mathrm{Helz}$ and Tossell, 2008), and $\mathrm{Cu}_{3} \mathrm{As}$, which is referred to as the mineral domeykite (Barin, 1995).

StabCal, a thermodynamic stability calculation program (Young and Huang, 1996; Huang et al. 2005; Huang, 2011), was used to create mass-balanced $\mathrm{E}_{\mathrm{H}-\mathrm{pH}}$ diagrams with $\mathrm{Cu}-\mathrm{As}-\mathrm{S}$ molar concentrations of enargite, 0.75:0.25:1 (see Figure 1). Mass balancing constrains thermodynamic calculations making them more accurate (Gow et al. 2014c) which is critical for ternary and higher order systems. This is explored further by varying the molecular ratios according to the stoichiometries of the other $\mathrm{Cu}$-As-S sulfosalts to determine the roles of copper, arsenic and sulfur in the stability of various solids, particularly sulfides (Gow et al. 2014d).

There are a few differences in the diagrams when compared to those previously published by Padilla et al. (2008), namely the inclusions of the minerals olivenite $\left(\mathrm{Cu}_{2} \mathrm{AsO}_{4} \mathrm{OH}\right)$ and domeykite $\left(\mathrm{Cu}_{3} \mathrm{As}\right)$. There are also instances of curvature in the equilibrium lines which can only be determined through the mass-balanced calculation method. The curvature indicates a balance between two competing equilibriua. In the case of Figure 1B this occurs this curvature occurs between enargite $\left(\mathrm{Cu}_{3} \mathrm{AsS}_{4}\right)$ and thioarsenate $\left(\mathrm{AsS}_{4}{ }^{3-}\right)$. Because these diagrams only show the predominant arsenic-containing species it is not readily apparent that the equilibrium reactions between these two species must also contain arsenate $\left(\mathrm{HAsO}_{4}{ }^{2-}\right)$ in order to mass balance, according to the following reactions:

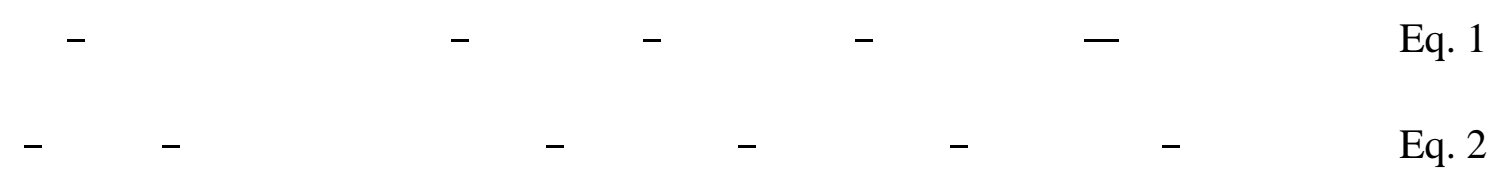


Due to the nature of the equations, Eq. 1 is a horizontal line controlled by pH whereas Eq. 2 is an electrochemical reaction where a small amount of arsenic is reduced. By combing the two competing reactions, the curvature becomes apparent.

There are also differences between the two diagrams and are attributed to sulfur oxidation. Figure 1A was created with consideration of sulfate species whereas Figure 1B was created without. In this regard, Figure 1A predicts enargite oxidation to sulfate and Figure 1B predicts oxidation to elemental sulfur. This approach of calculating $\mathrm{E}_{\mathrm{H}} \mathrm{pH}$ diagrams for kinetic purposes has been used extensively in the literature (Huang and Young, 1986; Woods et al., 1987). It should also be noted that the thermodynamic data for metastable copper sulfides were included in the calculations and they were determined to be stable as thin regions between covellite and chalcocite similar to Woods et al. (1987) and Young et al. (1988); however, their regions of predominance were excluded for easier comprehension of the diagram. The shaded regions in each diagram are areas where solid arsenic species do not exist and would therefore determine conditions where arsenic could be selectively leached. Theoretically, according to these thermodynamic calculations, there is a region where this would occur and, for the most part, it is independent of the sulfur oxidation state and occurs under basic conditions $(\sim \mathrm{pH}>9)$ but slightly oxidizing $\left(\sim \mathrm{E}_{\mathrm{H}}>-500 \mathrm{mV}\right)$. Raman spectroscopy and cyclic voltammetry were used in this study to modify and/or confirm the predicted predominance diagrams with the objective to determine if enargite oxidation proceeds to elemental sulfur or goes as far as sulfate (or some other sulfoxy ion). 
Table 1. Standard Free Energy Values for Cu-As-S Species.

Primary database used was MINTEQA2 unless otherwise indicated.

\begin{tabular}{|c|c|c|c|c|c|}
\hline Species & $\Delta G^{0}$ (kcal) & Ref & Species & $\Delta \mathrm{G}^{\mathbf{0}}(\mathrm{kcal})$ & Ref. \\
\hline \multicolumn{6}{|c|}{ Water } \\
\hline $\mathrm{H}_{2} \mathrm{O}$ (liquid) & -56.67 & & $\mathrm{H}^{+}$ & 0 & \\
\hline \multicolumn{6}{|c|}{ Copper (aqueous) } \\
\hline $\mathrm{Cu}^{+}$ & 11.982 & & $\mathrm{Cu}_{2} \mathrm{~S}_{3}{ }^{2-}$ & 43.307 & \\
\hline $\mathrm{Cu}^{2+}$ & 15.652 & & $\mathrm{CuS}$ & 22.359 & \\
\hline $\mathrm{CuOH}^{+}$ & -30.795 & & $\mathrm{Cu}\left(\mathrm{S}_{4}\right)_{2}{ }^{3-}$ & 13.131 & \\
\hline $\mathrm{Cu}_{2} \mathrm{OH}^{3+}$ & -16.217 & & $\mathrm{CuS}_{4} \mathrm{~S}_{5}{ }^{3-}$ & 14.127 & \\
\hline $\mathrm{Cu}(\mathrm{OH})_{4}{ }^{2-}$ & -156.846 & & $\mathrm{CuSO}_{4}$ & -165.46 & \\
\hline $\mathrm{Cu}(\mathrm{OH})_{3}^{-}$ & -118.029 & & $\mathrm{CuHSO}_{4}{ }^{+}$ & -165.432 & \\
\hline $\mathrm{Cu}(\mathrm{OH})_{2}$ & -75.556 & & $\mathrm{Cu}\left(\mathrm{SO}_{3}\right)_{2}{ }^{3-}$ & -232.439 & \\
\hline $\mathrm{Cu}_{2}(\mathrm{OH})_{2}{ }^{2+}$ & -67.73 & & $\mathrm{CuSO}_{3}$ & -115.563 & \\
\hline $\mathrm{Cu}_{3}(\mathrm{OH})_{4}{ }^{2+}$ & -151.384 & & $\mathrm{CuSO}_{3}$ & -107.977 & \\
\hline \multicolumn{6}{|c|}{ Copper (solid) } \\
\hline $\mathrm{Cu}$ & 0 & & $\mathrm{Cu}_{2} \mathrm{~S}$ Chalcocite & -21.319 & Potter \\
\hline $\mathrm{Cu}_{2} \mathrm{O}$ Cuprite & -35.325 & Robie & $\mathrm{Cu}_{1.95} \mathrm{~S}$ Djurleite & -20.124 & \\
\hline $\mathrm{CuO}$ Tenorite & -30.664 & Robie & $\mathrm{Cu}_{1.75} \mathrm{~S}$ Anilite & -18.762 & \\
\hline $\mathrm{Cu}(\mathrm{OH})_{2}$ & -85.024 & & CuS Covellite & -12.491 & Potter \\
\hline $\mathrm{Cu}_{2} \mathrm{SO}_{4}$ & -156.588 & & $\mathrm{Cu}_{3} \mathrm{SO}_{4}(\mathrm{OH})_{4}$ Antlerite & -345.647 & \\
\hline $\mathrm{CuSO}_{4}$ Chalcocyanite & -158.293 & Robie & $\mathrm{Cu}_{4} \mathrm{SO}_{4}(\mathrm{OH})_{6}$ Brochantite & -434.512 & Robie \\
\hline $\mathrm{CuSO}_{4} \cdot 5 \mathrm{H}_{2} \mathrm{O}$ Chalcanthite & -449.331 & Robie & $\mathrm{Cu}_{4} \mathrm{SO}_{4}(\mathrm{OH})_{6} \cdot \mathrm{H}_{2} \mathrm{O}$ Langite & -488.15 & \\
\hline $\mathrm{CuO}: \mathrm{CuSO}_{4}$ & -189.207 & & $\mathrm{Cu}_{1.93} \mathrm{~S}$ & -19.99 & Koch \\
\hline $\mathrm{Cu}_{1.83} \mathrm{~S}$ & -19.19 & Koch & $\mathrm{Cu}_{1.67} \mathrm{~S}$ & -17.79 & Koch \\
\hline $\mathrm{Cu}_{1.40} \mathrm{~S}$ & -15.378 & Potter & $\mathrm{Cu}_{1.38} \mathrm{~S}$ & -15.09 & Koch \\
\hline $\mathrm{Cu}_{1.12} \mathrm{~S}$ & -13.586 & Potter & & & \\
\hline \multicolumn{6}{|c|}{ Copper (metastable solids) } \\
\hline $\mathrm{CuS}$ & -11.24 & Koch & $\mathrm{Cu}_{1.965} \mathrm{~S}$ & -0.73 & Etienne \\
\hline $\mathrm{Cu}_{1.96} \mathrm{~S}$ & 0.21 & Matheiu & $\mathrm{Cu}_{1.95} \mathrm{~S}$ & 0.45 & Koch \\
\hline $\mathrm{Cu}_{1.92} \mathrm{~S}$ & 0.32 & Brage & $\mathrm{Cu}_{1.90} \mathrm{~S}$ & 0.62 & Matheiu \\
\hline $\mathrm{Cu}_{1.86} \mathrm{~S}$ & 1.24 & Koch & $\mathrm{Cu}_{1.79} \mathrm{~S}$ & 1.21 & Matheiu \\
\hline $\mathrm{Cu}_{1.77} \mathrm{~S}$ & 1.38 & Brage & $\mathrm{Cu}_{1.765} \mathrm{~S}$ & 0.83 & Etienne \\
\hline $\mathrm{Cu}_{1.68} \mathrm{~S}$ & 2.64 & Koch & $\mathrm{Cu}_{1.60} \mathrm{~S}$ & 2.86 & Brage \\
\hline $\mathrm{Cu}_{1.40} \mathrm{~S}$ & 5.15 & Koch & $\mathrm{Cu}_{1.31} \mathrm{~S}$ & 6.65 & Brage \\
\hline \multicolumn{6}{|c|}{ Sulfur (aqueous) } \\
\hline $\mathrm{S}^{2-}$ & 26.625 & & $\mathrm{SO}_{4}{ }^{2-}$ & -177.892 & \\
\hline $\mathrm{HS}^{-}$ & 2.887 & & $\mathrm{HSO}_{4}{ }^{-}$ & -180.607 & \\
\hline Species & $\Delta G^{0}$ (kcal) & Ref & Species & $\Delta \mathbf{G}^{\mathbf{0}}$ (kcal) & Ref. \\
\hline $\mathrm{H}_{2} \mathrm{~S}$ & -6.69 & & $\mathrm{SO}_{3}{ }^{2-}$ & -116.276 & \\
\hline $\mathrm{S}_{2}{ }^{2-}$ & 18.962 & & $\mathrm{HSO}_{3}{ }^{-}$ & -126.085 & \\
\hline $\mathrm{S}_{3}{ }^{2-}$ & 17.575 & & $\mathrm{H}_{2} \mathrm{SO}_{3}$ & -128.609 & \\
\hline $\mathrm{S}_{4}{ }^{2-}$ & 16.476 & & $\mathrm{~S}_{2} \mathrm{O}_{3}{ }^{2-}$ & -124.881 & \\
\hline
\end{tabular}




\begin{tabular}{|c|c|c|c|c|c|}
\hline $\mathrm{S}_{5}^{2-}$ & 15.663 & & $\mathrm{HS}_{2} \mathrm{O}_{3}{ }^{-}$ & -127.064 & \\
\hline $\mathrm{S}_{6}{ }^{2-}$ & 16.367 & & $\mathrm{H}_{2} \mathrm{~S}_{2} \mathrm{O}_{3}$ & -127.882 & \\
\hline $\mathrm{S}_{2} \mathrm{O}_{5}{ }^{2-}$ & -197.528 & & & & \\
\hline \multicolumn{6}{|c|}{ Sulfur (solid) } \\
\hline S Sulfur & 0 & & & & \\
\hline \multicolumn{6}{|c|}{ Sulfur (gas) } \\
\hline $\mathrm{H}_{2} \mathrm{~S}$ & -8.041 & & $\mathrm{SO}_{2}$ & -71.811 & \\
\hline \multicolumn{6}{|c|}{ Arsenic (aqueous) } \\
\hline $\mathrm{AsO}_{3}{ }^{3-}$ & 102.9 & & $\mathrm{AsO}_{4}{ }^{3-}$ & -154.974 & \\
\hline $\mathrm{HAsO}_{3}{ }^{2-}$ & -121.105 & & $\mathrm{HAsO}_{4}{ }^{2-}$ & -171.072 & \\
\hline $\mathrm{H}_{2} \mathrm{AsO}_{3}{ }^{-}$ & -140.341 & & $\mathrm{H}_{2} \mathrm{AsO}_{4}{ }^{-}$ & -180.608 & \\
\hline $\mathrm{H}_{3} \mathrm{AsO}_{3}$ & -152.851 & & $\mathrm{H}_{3} \mathrm{AsO}_{4}{ }^{-}$ & -183.746 & \\
\hline $\mathrm{AsO}^{+}$ & -39.15 & & $\mathrm{AsSO}_{3}{ }^{3-}$ & -118.73 & \\
\hline $\mathrm{HAsSO}_{2}{ }^{2-}$ & -79.128 & & $\mathrm{HAsSO}_{3}{ }^{2-}$ & -133.737 & \\
\hline $\mathrm{H}_{3} \mathrm{AsSO}_{2}$ & $-103.412^{g}$ & Helz & $\mathrm{H}_{2} \mathrm{AsSO}_{3}{ }^{-}$ & -143.56 & \\
\hline $\mathrm{H}_{2} \mathrm{AsSO}_{2}^{-}$ & -98.364 & & $\mathrm{H}_{3} \mathrm{AsSO}_{3}$ & -148.062 & \\
\hline $\mathrm{H}_{3} \mathrm{AsSO}_{2}$ & -103.412 & & $\mathrm{HAsS}_{2} \mathrm{O}^{2-}$ & -41.793 & \\
\hline $\mathrm{AsS}_{2} \mathrm{O}_{2}{ }^{3-}$ & -77.029 & & $\mathrm{H}_{2} \mathrm{AsS}_{2} \mathrm{O}^{-}$ & -53.525 & \\
\hline $\mathrm{HAsS}_{2} \mathrm{O}_{2}{ }^{2-}$ & -91.763 & & $\mathrm{H}_{3} \mathrm{AsS}_{2} \mathrm{O}$ & -58.573 & \\
\hline $\mathrm{H}_{2} \mathrm{AsS}_{2} \mathrm{O}_{2}{ }^{-}$ & -101.449 & & $\mathrm{H}_{2} \mathrm{AsS}_{3} \mathrm{O}^{-}$ & -55.246 & \\
\hline $\mathrm{H}_{3} \mathrm{AsS}_{2} \mathrm{O}_{2}$ & -98.175 & & $\mathrm{H}_{3} \mathrm{AsS}_{3} \mathrm{O}$ & -52.927 & \\
\hline $\mathrm{AsS}_{3} \mathrm{O}^{3-}$ & -38.466 & & $\mathrm{AsS}_{4}{ }^{3-}$ & -0.448 & \\
\hline $\mathrm{HAsS}_{3} \mathrm{O}^{2-}$ & -53.2 & & $\mathrm{HAsS}_{4}{ }^{2-}$ & -7.542 & \\
\hline $\mathrm{HAsS}_{3}{ }^{2-}$ & 0.591 & & $\mathrm{H}_{2} \mathrm{AsS}_{4}^{-}$ & -9.589 & \\
\hline $\mathrm{H}_{2} \mathrm{AsS}_{3}{ }^{-}$ & -11.142 & & $\mathrm{H}_{3} \mathrm{AsS}_{4}$ & -6.451 & \\
\hline $\mathrm{H}_{3} \mathrm{AsS}_{3}$ & -16.19 & & $\mathrm{H}_{2} \mathrm{As}_{3} \mathrm{~S}_{6}{ }^{-}$ & -33.22 & \\
\hline $\mathrm{As}_{3} \mathrm{~S}_{6}{ }^{3-}$ & -13.15 & & $\mathrm{H}_{3} \mathrm{As}_{3} \mathrm{~S}_{6}$ & -43.02 & \\
\hline $\mathrm{HAs}_{3} \mathrm{~S}_{6}{ }^{2-}$ & -25.33 & & & & \\
\hline \multicolumn{6}{|c|}{ Arsenic (solid) } \\
\hline $\mathrm{As}_{2} \mathrm{O}_{3}$ Arsenolite & -137.667 & Robie & $\mathrm{As}_{2} \mathrm{~S}_{3}$ (amorphous) & -18.246 & \\
\hline $\mathrm{As}_{2} \mathrm{O}_{3}$ Claudetite & -137.572 & Robie & $\mathrm{As}_{2} \mathrm{~S}_{3}$ Orpiment & -21.606 & Robie \\
\hline $\mathrm{As}_{2} \mathrm{O}_{5}$ & -187.249 & & AsS Realgar & -7.075 & Robie \\
\hline \multicolumn{6}{|c|}{ Copper Arsenic (solid) } \\
\hline $\mathrm{Cu}_{3} \mathrm{AsS}_{4}$ Enargite & -49.808 & Craig & $\mathrm{Cu}_{3}$ As Domeykite & -3.184 & Barin \\
\hline $\mathrm{Cu}_{6} \mathrm{As}_{4} \mathrm{~S}_{9}$ Sinnerite & -110.256 & Craig & $\mathrm{Cu}_{3} \mathrm{AsS}_{4}$ Luzonite & NA & \\
\hline $\mathrm{Cu}_{12} \mathrm{As}_{4} \mathrm{~S}_{13}$ Tennantite & $-180.908^{h}$ & Craig & CuAsS Lautite & NA & \\
\hline $\mathrm{Cu}_{3}\left(\mathrm{AsO}_{4}\right)_{2}: 2 \mathrm{H}_{2} \mathrm{O}$ & -424.227 & & $\mathrm{Cu}\left(\mathrm{AsO}_{2}\right)_{2}$ & $-169.2^{j}$ & Nishimura \\
\hline $\mathrm{Cu}_{2} \mathrm{AsO}_{4} \mathrm{OH}$ & -201.9 & & & & \\
\hline
\end{tabular}



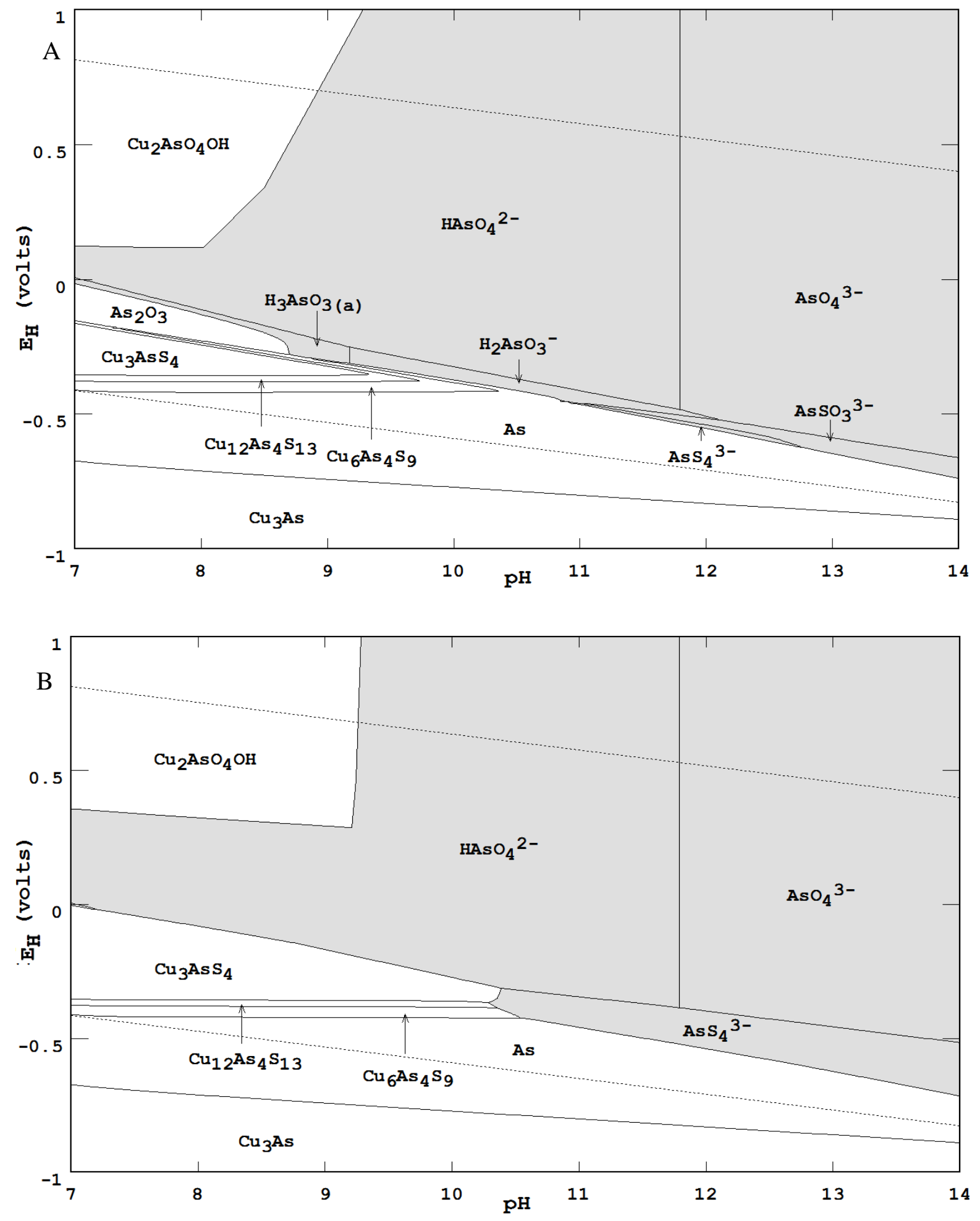

Figure 1 - Mass-balanced $\mathrm{E}_{\mathrm{H}}-\mathrm{pH}$ Diagrams for the $\mathrm{Cu}-\mathrm{As}-\mathrm{S}-\mathrm{H}_{2} \mathrm{O}$ system as determined for Ascontaining species $([\mathrm{Cu}]=0.075 \mathrm{M},[\mathrm{As}]=0.025 \mathrm{M},[\mathrm{S}]=0.10 \mathrm{M}) \mathrm{A}$. Oxidation to Sulfate and B. Oxidation to Sulfur. The dashed lines indicate the region of water stability and shaded regions are predominance areas for aqueous species (Small binary regions are not labelled for clarity). 


\section{Materials and Methods}

Enargite samples were obtained from Butte, MT and Quiruvilca, Peru. Both samples were characterized with Scanning Electron Microscopy/Mineral Liberation Analysis (SEM/MLA) as shown in Table 2. The Peru sample is $\sim 98 \%$ pure with $78 \%$ minor antimony ( $\mathrm{Sb}$ ) substitution. By comparison, the Butte sample was $\sim 83 \%$ enargite but with only $55 \%$ of minor $\mathrm{Sb}$ substitution; however, the sample did contain significant amounts of chalcopyrite (14.5\%).

Table 2: SEM/MLA Sample Composition of Enargite Samples

\begin{tabular}{l|c|c|c|c|c|} 
& \multicolumn{1}{c}{ Enargite w/ Sb } & \multicolumn{1}{c}{ Enargite } & \multicolumn{1}{c}{ Chalcopyrite } & Quartz & Feldspar \\
\cline { 2 - 6 } Butte & 54.97 & 28.09 & 14.47 & 2.24 & 0.23 \\
\cline { 2 - 6 } Peru & 77.93 & 19.69 & 0.03 & 2.35 & 0.01 \\
\cline { 2 - 6 }
\end{tabular}

Once the samples were characterized, sections with a surface area measuring approximately $0.25 \mathrm{~cm}^{2}$ were cut from each. After a copper wire was attached to the back side of the enargite samples using Electrodag 502 and carbon tape, the assemblies were mounted into polytetraflouroethylene (PTFE) tubing and then sealed in the tubing using a non-conductive epoxy resin. Conductivity measurements showed the mineral electrodes were ready for the spectroelectrochemical studies. Raman spectra and cyclic voltammograms collected from the two electrodes yielded the same results and were virtually indistinguishable. Consequently, it did not need to be reported which results were obtained from which sample/electrode. In between these spectroelectrochemical measurements, the exposed face was polished with 200grit $\mathrm{SiC}$ sandpaper and cleaned with de-ionized water.

Raman studies were conducted at Griffith University in Brisbane, Australia. In-situ studies were conducted using a Renishaw Raman 100 InVia spectrophotometer. The system has a 100-mW $\mathrm{He}-\mathrm{Ne}$ laser as the excitation source $(632.8 \mathrm{~nm})$, a MultiPhysics 1000-line grating, 2 Rayleighscatter filters, and a $256 \times 512 \mathrm{CCD}$ array as the detector. Raman spectra were calibrated using the $520 \mathrm{~cm}^{-1}$ primary band of pure silicon. The system programming was controlled by the GRAMS spectrometer software suite. Because of the selected optics, detection of peaks below $200 \mathrm{~cm}^{-1}$ was not entirely reliable and, as a result, peak characterization was presumably conducted on the less intense peaks at higher wavenumbers. The $\mathrm{pH}$ was controlled by buffers that were created according to the CRC Handbook (Haynes, 2011). The buffers included borate for $\mathrm{pH} 8$ and 9, bicarbonate for $\mathrm{pH} 10$ and 11, and chloride for $\mathrm{pH} 12$ and 13. No buffer effects were observed in any of the experiments.

Ex-situ spectra were collected using a Renishaw Raman RM2000 InVia spectrophotometer, also with a $632.8 \mathrm{~nm}$ HeNe laser, using a Peltier-cooled CCD detector. The attached Leica LMDM microscope allows for a rapid visual inspection of the electrode surface with up to $600 \mathrm{x}$ magnification. Because the enargite electrodes and surface species were easily burned under full laser intensity, the power was reduced to $10 \%$ or less. In addition, the number of scans was increased to 5 with $>10$ second exposure to maximize the Raman signal. The system was controlled by the Renishaw WiRE 3.2 software package.

\section{Static Tests}

Initially, the $\mathrm{pH}$ and potential conditions were held constant for various defined points of interest on the $\mathrm{Cu}$-As- $\mathrm{S} \mathrm{E}_{\mathrm{H}} \mathrm{pH}$ diagram while spectra were collected for up to $24 \mathrm{hrs}$. These tests were 
used to identify Raman peak positions of the major mineral phases. The electrodes were held under potentiostatic control until removed from the solution and then dried under nitrogen gas. Spectra of the surface were collected with the RM2000 at $10 \%$ laser power.

\section{Multifiles}

The multifiles combine a continuously scanning program for the collection of Raman spectra which occurs every five seconds and are linked to the cyclic voltammograms. The electrodes were cycled three times, scanning initially in either the negative or positive directions but typically at a scan rate of $5 \mathrm{mV} / \mathrm{sec}$ between -1000 and $+1000 \mathrm{mV}$. There is a time delay between changes in the current density slope and when the Raman detected composition changes in order to maximize Raman signals. However, it is noted that the Raman spectra are therefore collected over a range of potentials. In this regard, slow scan rates or constant potentials are preferred so that the Raman spectra can be linked to the voltammograms, and therefore the $\mathrm{E}_{\mathrm{H}^{-}}$ $\mathrm{pH}$ diagrams, as best as possible.

For cyclic voltammetry, liquid samples were contained in a 5-port electrochemical cell. The cell was clipped into a holding bracket, which allowed horizontal and vertical adjustment to center the focal point of the laser. The port closest to the laser was used for the enargite electrode while the others were used for the $\mathrm{Ag} / \mathrm{AgCl}$ saturated $\mathrm{KCl}(+0.197 \mathrm{mV}$ vs SHE) reference electrode and a platinum counter electrode. As the enargite electrodes were tested interchangeable, and their surface areas were not exact, voltammograms are scaled by current (A) instead of current density $\left(\mathrm{A} / \mathrm{m}^{2}\right)$. Potentials at which reactions occur are plotted against the mass balanced $\mathrm{E}_{\mathrm{H}-\mathrm{pH}}$ diagrams for reaction determination instead of identification using peak areas.

\section{Raman Spectroscopy}

The reference peaks for enargite appear at 265, 338, 384, 679 and $725 \mathrm{~cm}^{-1}$ (see Figure 2). For consistency, these spectra and others were compared against the RRUFF Raman mineral spectroscopic database (Downs, 2006). Tennantite $\left(\mathrm{Cu}_{12} \mathrm{As}_{4} \mathrm{~S}_{13}\right)$, chalcocite $\left(\mathrm{Cu}_{2} \mathrm{~S}\right)$, covellite $(\mathrm{CuS})$, olivenite $\left(\mathrm{Cu}_{2} \mathrm{AsO}_{4} \mathrm{OH}\right)$, elemental copper, elemental sulfur, and pyrite $\left(\mathrm{FeS}_{2}\right)$ were identified in this manner. Copper (II) hydroxide formation was identified via precipitation during testing. Tennanite was identified by the reversal of peak intensities for peaks at 338 and $384 \mathrm{~cm}^{-1}$, although it did not completely reflect the spectra in the Raman database. There are no known spectra for sinnerite or lautite, and none of the experimental results could be attributed to them based on common bonds.

Sulfur on enargite was identified first at $\mathrm{pH} 9$ and $0 \mathrm{mV}$ vs SHE as shown in Figure 3. The reference peaks for elemental sulfur at 150,220 and $470 \mathrm{~cm}^{-1}$ are included for comparison. The surface usually indicated a $\mathrm{CuS}$ phase, often with a characteristic peak at $470 \mathrm{~cm}^{-1}$ before the sulfur peaks would build in intensity. The presence of sulfur was followed by a drop in current density which then indicated no further reaction occurring and likely passivation of the surface.

\section{Cyclic Voltammetry}

Cycling the electrode gave relatively the same pattern of voltammograms, independent of cycle number. A typical example is shown in Figure 4 for voltammograms obtained at $\mathrm{pH} 8$ at a scan rate of $5 \mathrm{mV} / \mathrm{sec}$ with an initial potential of $-200 \mathrm{mV}$ and lower and upper potentials of -1200 and $+800 \mathrm{mV}$ vs sat. $\mathrm{Ag} / \mathrm{AgCl}$ (+197 mV vs SHE), respectively. 


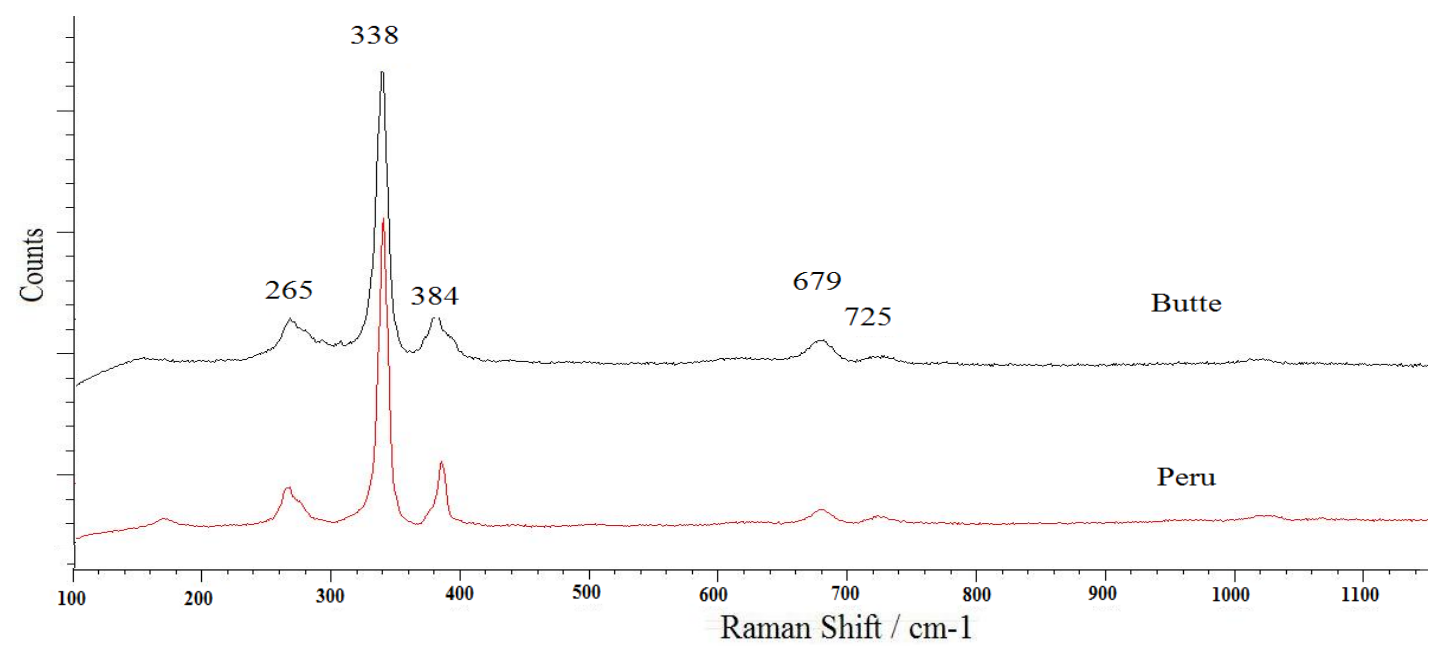

Figure 2 - Raman spectra of the solid enargite electrodes used in this study

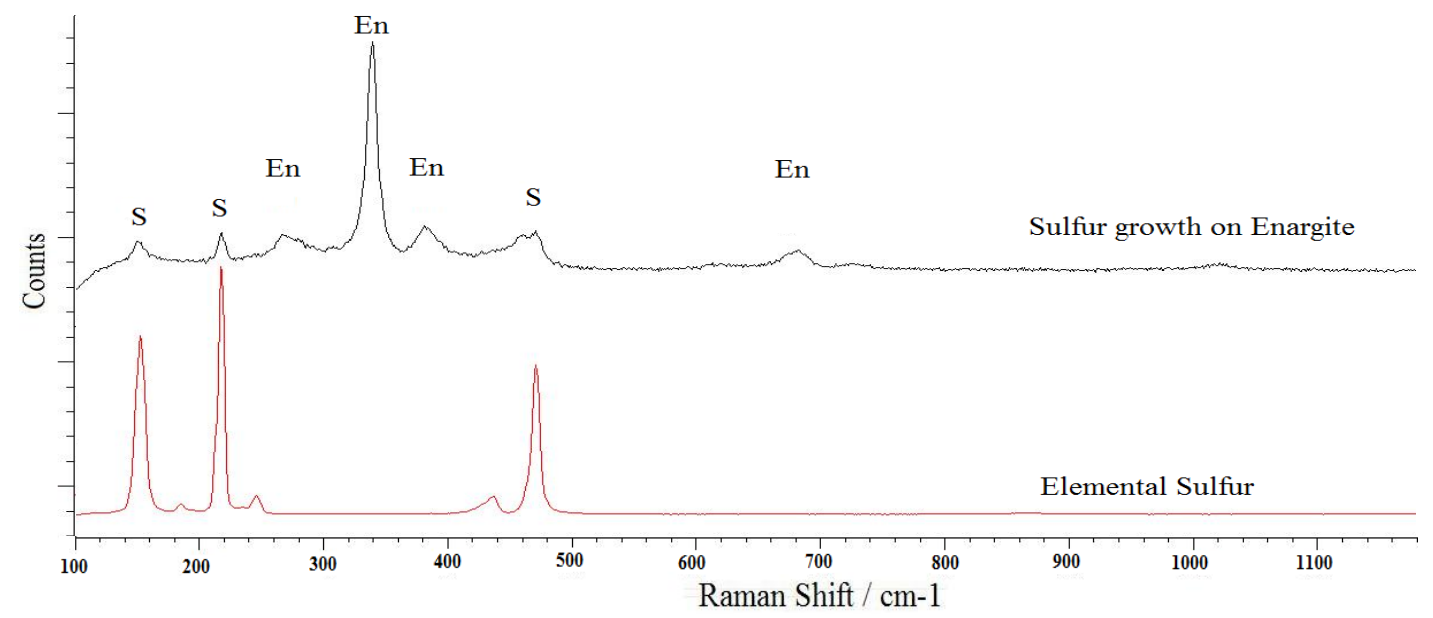

Figure 3 - Sulfur Growth on Enargite Surface (pH 9, 0 mV, 60 min)

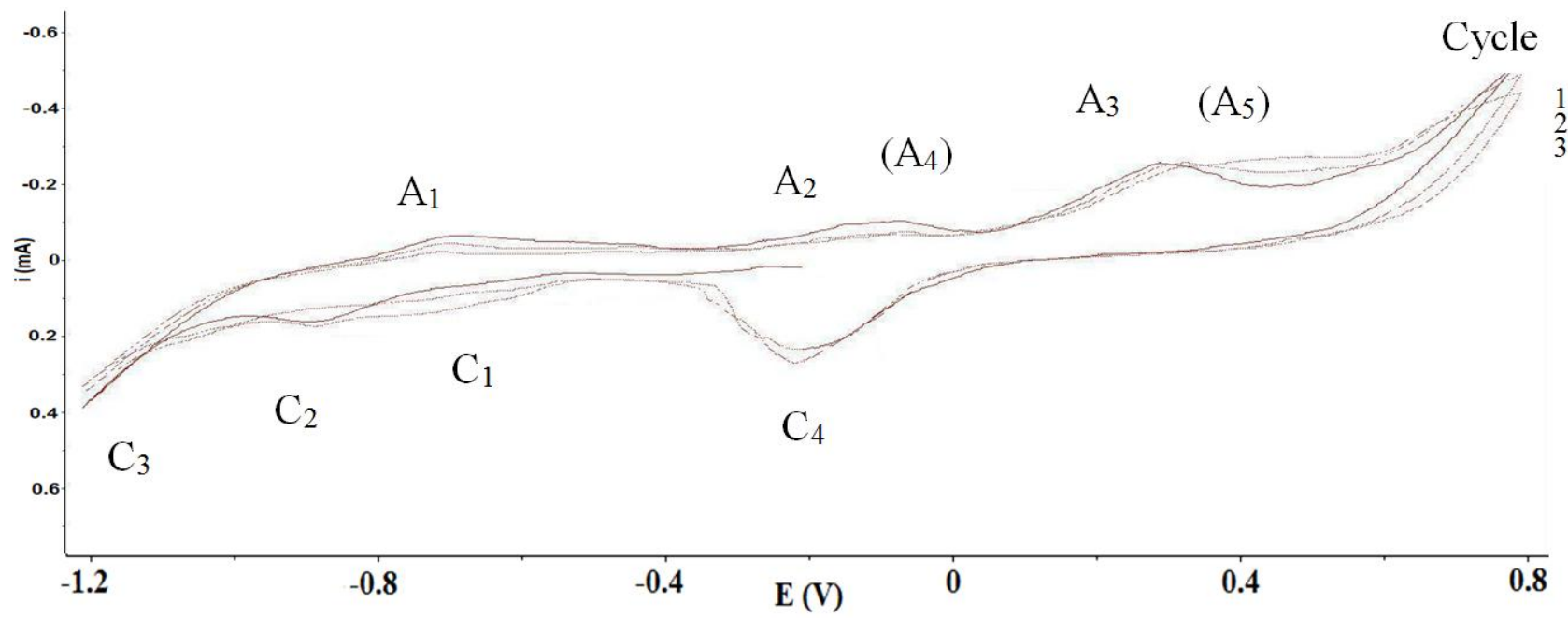

Figure 4 - Peru enargite sample at pH 8, scanning negatively from $-200 \mathrm{mV}, 5 \mathrm{mV} / \mathrm{s}$ scan rate 
In this example, resulting peaks on the cathodic scan suggest enargite reduces to tennantite, where the arsenic is partially reduced from its +5 state to +3 . Further reduction of the surface converts to chalcocite and finally elemental copper as depicted in the following reduction reactions and observed from the Raman spectra collected simultaneously:

$$
\begin{array}{lll}
4 \mathrm{Cu}_{3} \mathrm{AsS}_{4}+3 \mathrm{H}^{+}+6 \mathrm{e}^{-}=\mathrm{Cu}_{12} \mathrm{As}_{4} \mathrm{~S}_{13}+3 \mathrm{HS}^{-} & \mathrm{E}^{0}=-0.195 & \text { Eq. 3 (C1) } \\
\mathrm{Cu}_{12} \mathrm{As}_{4} \mathrm{~S}_{13}+\mathrm{H}^{+}+2 \mathrm{e}^{-}=\mathrm{Cu}_{6} \mathrm{As}_{4} \mathrm{~S}_{9}+3 \mathrm{Cu}_{2} \mathrm{~S}+\mathrm{HS}^{-} & \mathrm{E}^{0}=-0.208 & \text { Eq. } 4(\mathrm{C} 2 \mathrm{a}) \\
\mathrm{Cu}_{6} \mathrm{As}_{4} \mathrm{~S}_{9}+2 \mathrm{H}^{+}+4 \mathrm{e}^{-}=3 \mathrm{Cu}_{2} \mathrm{~S}+4 \mathrm{AsS}+2 \mathrm{HS}^{-} & \mathrm{E}^{0}=-0.258 & \text { Eq. 5 (C2b) } \\
\mathrm{Cu}_{2} \mathrm{~S}+\mathrm{H}^{+}+2 \mathrm{e}^{-}=2 \mathrm{Cu}^{\mathrm{o}}+\mathrm{HS}^{-} & \mathrm{E}^{0}=-0.525 & \text { Eq. 6 (C3) }
\end{array}
$$

It is noted that domeykite $\left(\mathrm{Cu}_{3} \mathrm{As}\right)$ was not observed as predicted thermodynamically in the $\mathrm{E}_{\mathrm{H}^{-}}$ $\mathrm{pH}$ diagrams presented earlier in Figures $1 \mathrm{~A}$ and $\mathrm{B}$. In this regard, an $\mathrm{E}_{\mathrm{H}}-\mathrm{pH}$ diagram will be redetermined without considering domeykite as presented and discussed later. On the other hand, sinnerite $\left(\mathrm{Cu}_{6} \mathrm{As}_{4} \mathrm{~S}_{9}\right)$ was also not observed but will not be excluded from consideration because it is expected that its stability range will be narrow and may not be detected spectroelectrochemically. Consequently, resulting tennantite may reduce to form sinnerite as an intermediate product as shown with Reactions $\mathrm{C} 2 \mathrm{a}$ and $\mathrm{C} 2 \mathrm{~b}$. Unfortunately, Raman spectra could not confirm realgar (AsS) or orpiment $\left(\mathrm{As}_{2} \mathrm{~S}_{3}\right)$ as reaction products but Reaction $\mathrm{C} 2$ is the only thermodynamically acceptable prediction.

After reversing the scan direction, Figure 4 also reveals anodic peaks which correspond to copper oxidation to chalcocite, then covellite, and finally elemental sulfur as depicted in the following oxidation reactions and observed from the Raman spectra collected simultaneously:

$$
\begin{array}{lll}
2 \mathrm{Cu}^{0}+\mathrm{HS}^{-}=\mathrm{Cu}_{2} \mathrm{~S}+\mathrm{H}^{+}+2 \mathrm{e}^{-} & \mathrm{E}^{0}=-0.525 & \text { Eq. } 7 \text { (A1) } \\
\mathrm{Cu}_{2} \mathrm{~S}+\mathrm{HS}^{-}=2 \mathrm{CuS}+\mathrm{H}^{+}+2 \mathrm{e}^{-} & \mathrm{E}^{0}=-0.142 & \text { Eq. } 8 \text { (A2) } \\
\mathrm{CuS}+2 \mathrm{H}_{2} \mathrm{O}=\mathrm{Cu}(\mathrm{OH})_{2}+\mathrm{S}^{\mathrm{o}}+2 \mathrm{H}^{+}+2 \mathrm{e}^{-} & \mathrm{E}^{0}=0.885 & \text { Eq. } 9 \text { (A3a) }
\end{array}
$$

Interestingly, not only were the two sulfides spectroelectrochemically observed but so was cupric hydroxide $\left(\mathrm{Cu}(\mathrm{OH})_{2}\right)$ precipitate. It has been noted that this precipitate solubilizes in borate (Young et al., 1988) which is present in the buffer solutions at this $\mathrm{pH}$. This could explain why olivenite $\left(\mathrm{Cu}_{2} \mathrm{AsO}_{4} \mathrm{OH}\right)$ was also periodically observed albeit in more significant amounts at $\mathrm{pH}$ 9 which is also comprised of a borate buffer. Olivenite was not observed until potentials reached $\sim 500 \mathrm{mV}$ vs SHE. In this regard, it is suggested that anodic reaction A3 also be represented as:

$$
2 \mathrm{CuS}+\mathrm{AsO}_{4}{ }^{3-}+\mathrm{H}_{2} \mathrm{O}=\mathrm{Cu}_{2} \mathrm{AsO}_{4} \mathrm{OH}+2 \mathrm{~S}^{\mathrm{o}}+\mathrm{H}^{+}+4 \mathrm{e}^{-} \quad \mathrm{E}^{0}=0.376 \quad \text { Eq. } 10 \text { (A3b) }
$$

such that the arsenate $\left(\mathrm{AsO}_{4}{ }^{3-}\right)$ likely comes from the oxidation of realgar (AsS):

$$
\mathrm{AsS}+4 \mathrm{H}_{2} \mathrm{O}=\mathrm{AsO}_{4}{ }^{3-}+\mathrm{S}^{\mathrm{o}}+8 \mathrm{H}^{+}+5 \mathrm{e}^{-} \quad \mathrm{E}^{0}=0.683 \quad \text { Eq. } 11 \text { (A4) }
$$

where the realgar is presumed to be present as a result of cathodic reaction $\mathrm{C} 2 \mathrm{~b}$. However, it is also conceivable that enargite itself oxidizes to arsenate and precipitates out as olivenite and covellite:

$$
\mathrm{Cu}_{3} \mathrm{AsS}_{4}+5 \mathrm{H}_{2} \mathrm{O}=\mathrm{Cu}_{2} \mathrm{AsO}_{4} \mathrm{OH}+\mathrm{CuS}+3 \mathrm{~S}^{\circ}+9 \mathrm{H}^{+}+9 \mathrm{e}^{-} \quad \mathrm{E}^{0}=0.572 \quad \text { Eq. } 12 \text { (A5) }
$$


Because Raman spectra showed elemental sulfur $\left(S^{\circ}\right)$ formed at each of the $\mathrm{pH}$ values investigated in this study, Reactions A3-A5 are all written with it as a product. This shows that, at least in the time frames examined in this study, enargite oxidizes to elemental sulfur and not sulfate. Consequently, the $\mathrm{E}_{\mathrm{H}} \mathrm{pH}$ diagram that will be redetermined, discussed and presented later will only consider oxidation to elemental sulfur and not sulfate.

It is important to note that these results strongly show that arsenic can be leached from enargite to form covellite and elemental sulfur. Periodically, the sulfur could not be observed until more than 1 cycle was conducted allowing for enough to accumulate. When that happened, the surface was observed to passivate. More importantly, the sulfur tended to accumulate more at $\mathrm{pH}$ 's above 10 where enargite is not stable. Under these conditions, enargite could not be regenerated during the voltametric studies. However, when the $\mathrm{pH}$ was below 10 , the enargite surface tended to regenerate as evidenced by the cathodic peak $\mathrm{C} 4$ in Figure 4 but more species than just enargite were observed.

\section{Updated Thermodynamics}

Based on the spectroelectrochemical results just presented, some modifications have been made to the $\mathrm{E}_{\mathrm{H}-\mathrm{pH}} \mathrm{diagrams}$ in Figure 1. Consequently, olivenite and sinnerite will continue to be considered and domeykite $\left(\mathrm{Cu}_{3} \mathrm{As}\right)$, cuprite $\left(\mathrm{Cu}_{2} \mathrm{O}\right)$ and tenorite $(\mathrm{CuO})$ will not. Furthermore, in regards to kinetics, only sulfide oxidation to elemental sulfur was allowed, so sulfoxy ions such as sulfate were not considered.

The resulting mass-balanced $\mathrm{E}_{\mathrm{H}-\mathrm{pH}} \mathrm{Hiagram}$ is shown in Figure 5. A comparison to Figure 1B shows that, by not considering domeykite, elemental copper becomes stable under the reducing conditions and both covellite and chalcocite stability regions increase. In addition, by not considering the copper oxides, olivenite has a larger stability region that increases from $\mathrm{pH} 9$ to 11. This decreases the area in which copper and arsenic can be separated by leaching and helps explain why sulfide leaching (including bisulfide and polysulfide leaching) is usually restricted to alkaline conditions at least $>\mathrm{pH} 11$ and typically $>\mathrm{pH} 12$ to insure selective leaching would occur. Furthermore, selectivity will be best achieved if the copper remains present as a solid sulfide, either as covellite or chalcocite, such that elemental sulfur formation would be prevented in order to avoid surface passivation and the risk of incomplete leaching. In this regard, leaching conditions should be kept $>\mathrm{pH} 12$ with $\mathrm{E}_{\mathrm{H}}$ between approximately $-600 \mathrm{mV}$ where thioarsenate $\left(\mathrm{AsS}_{4}{ }^{3-}\right)$ is stable and $+100 \mathrm{mV}$ where arsenate $\left(\mathrm{AsO}_{4}{ }^{3-}\right)$ is stable.

All voltammograms were then re-examined for inflection points in which increased current flow was observed thereby indicating an electrochemical reaction was starting to occur. The potentials where this occurred were plotted on the updated $\mathrm{E}_{\mathrm{H}}-\mathrm{pH}$ diagram and results are presented in Figure 6. Clearly, the potentials line up well with thermodynamic expectations and much better than would occur in Figure 1B. This suggests the diagram is accurate giving high confidence for the results presented in this study. It is noted that a series of points occur near 0 $\mathrm{mV}$ vs SHE at $\mathrm{pH} 10-13$ and are attributed to the formation of nonstoichiometric copper sulfides (Young et al. 1988) as chalcocite oxidizes to covellite. These points are not observed at lower $\mathrm{pH}$ values because chalcocite is not stable under these conditions (in the presence of arsenic). As noted earlier, the nonstoichiometric copper sulfides were stable according to the thermodynamic calculations but were not included in the $\mathrm{E}_{\mathrm{H}-\mathrm{pH}} \mathrm{piagrams}$ in Figures $1 \mathrm{~A}, 1 \mathrm{~B}, 5$ and 6 for clarity purposes. 


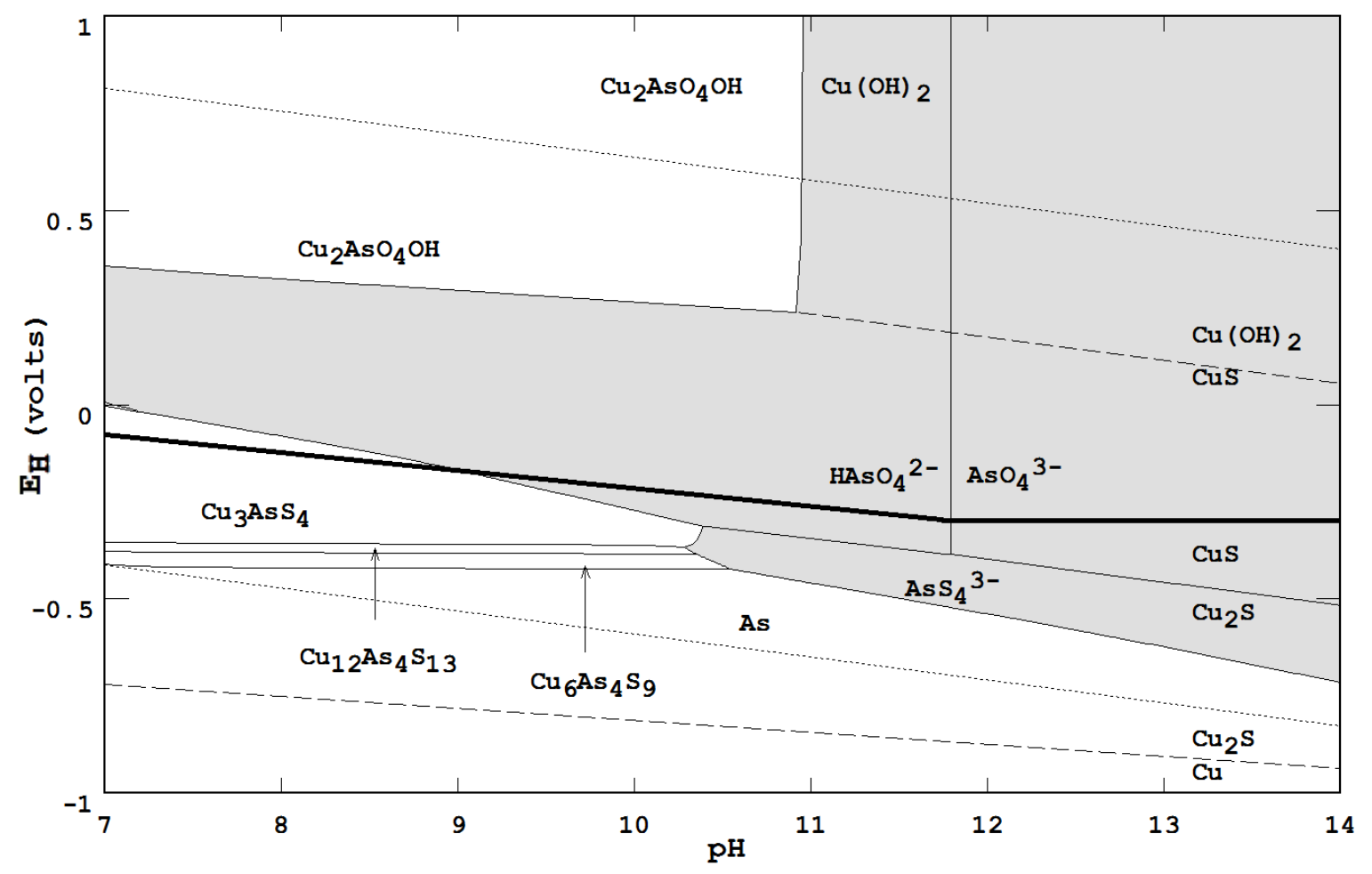

Figure 5 - Updated $\mathrm{E}_{\mathrm{H}-\mathrm{pH}} \mathrm{Diagram}$ for the $\mathrm{Cu}-\mathrm{As}-\mathrm{S}$ system with Region of Selective Leaching. The dotted line indicates the regions of water stability, copper-only transitions are indicated by the dashed line, and area above the bold line indicates stability of elemental sulfur.

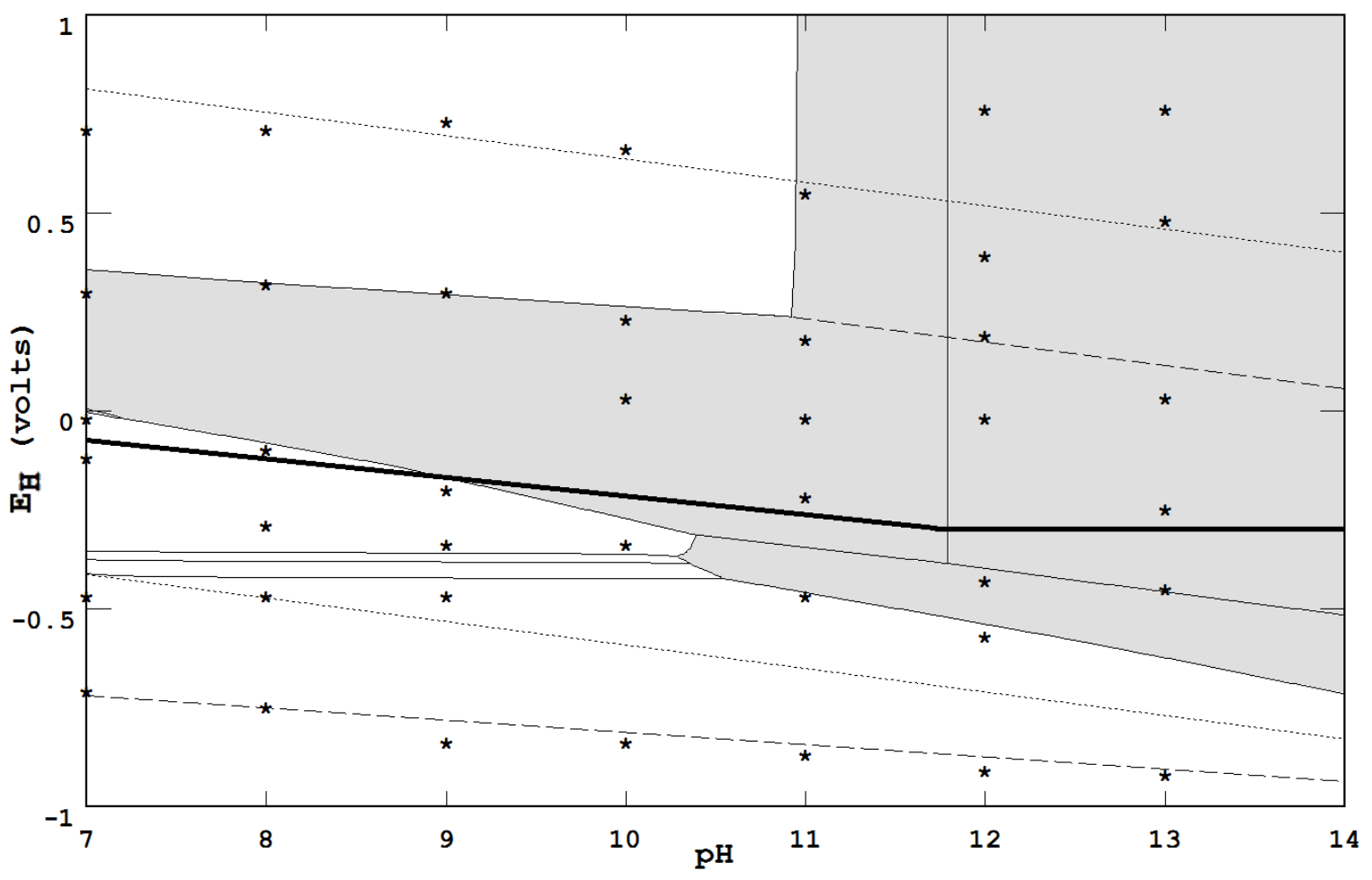

Figure 6 - Updated $\mathrm{E}_{\mathrm{H}} \mathrm{pH}$ Diagram for the $\mathrm{Cu}-\mathrm{As}-\mathrm{S}$ system overlaid with $\mathrm{CV}$ inflection points 


\section{Conclusions}

Enargite $\left(\mathrm{Cu}_{3} \mathrm{AsS}_{4}\right)$ electrodes were spectroelectrochemically studied under alkaline conditions at a $\mathrm{pH}$ range of 8-13 using Raman spectroscopy and cyclic voltammetry simultaneously in order to determine and compare surface species against theoretical $\mathrm{E}_{\mathrm{H}} \mathrm{pH}$ diagrams determined from mass-balanced thermodynamic calculations. Under slightly oxidizing conditions, covellite $(\mathrm{CuS})$ peaks were found in a short matter of time, above $~ 100 \mathrm{mV}$ vs SHE for $\mathrm{pH} 9-13$, suggesting arsenic leaching specifically occurred. At higher potentials and longer conditioning times, elemental sulfur was observed and tended to passivate the surface. The presence of sulfur suggests that copper was eventually leached. By operating above $\mathrm{pH} 12$, under slightly reducing conditions, elemental sulfur formation would be avoided between approximately $-700 \mathrm{mV}$ vs SHE where thioarsenate $\left(\mathrm{AsS}_{4}{ }^{3-}\right)$ forms and $+100 \mathrm{mV}$ vs SHE where thiosulfate $\left(\mathrm{AsO}_{4}{ }^{3-}\right)$ forms. An average potential near $-300 \mathrm{mV}$ vs SHE is therefore suggested to selectively leach arsenic from enargite and form covellite or chalcocite. Spectroelectrochemical results match up very well with a newly calculated mass-balanced $\mathrm{E}_{\mathrm{H}-\mathrm{pH}} \mathrm{Hiagram}$.

\section{References}

Allison, J., Brown, D. and Novo-Gradac, K., 1990, “MINTEQA2/PRODEFA2 A Geochemical Assessment Model for Environmental System", Version 3, Environmental Research Laboratory, EPA.

Anderson, C. and Twidwell, L., 2008 "Hydrometallurgical Processing of Gold-Bearing Copper Enargite Concentrates," Canadian Metallurgical Quarterly, Vol 47, No. 3, pp. 337-345.

Balaz, P. and Achimovicova, M., 2006 "Selective Leaching of Antimony and Arsenic from Mechanically Activated Tetrahedrite, Jamesonite and Enargite," International Journal of Mineral Processing, Vol. 81, pp. 44-50.

Barin, I., 1995, Thermochemical Data of Pure Substances, New York, NY VCH Publishers, Inc.

Brage, M., Lamache, M. and Bauer, D., 1979, "Contribution a l'etude des sulfres de cuivre non stoichiometriques," Electrochemica Acta, Vol. 24, pp 25-30.

Craig, J. and Barton, P., 1973, "Thermochemical Approximations for Sulfosalts", Economic Geology, Vol. 68, pp. 493-506.

Curreli, L., Ghiani, M., Surracco, M. and Orru, G., 2005, "Beneficiation of a Gold Bearing Enargite Ore by Flotation and As Leaching with Na-Hypochlorite," Minerals Engineering, Vol. 18, pp. 849-954.

Delfini, M., Ferrini, M., Manni, A., Massacci, P. and Piga, L., 2003 “Arsenic Leaching by $\mathrm{Na}_{2} \mathrm{~S}$ to decontaminate tailings coming from colemanite processing," Minerals Engineering, Vol. 16, pp. $45-50$.

Downs, R., 2006, "The RRUFF Project: an integrated study of the chemistry, crystallography, Raman and infrared spectroscopy of minerals," Program and Abstracts of the 19th General Meeting of the International Mineralogical Association in Kobe, Japan. 
Etienne, A. and Peters, E., 1972, "Thermodynamic Measurements in the Cu-S System in the Temperature Range $40-80^{\circ} \mathrm{C}$, IMM Transactions Section C, Vol. 81, pp 176-181.

Gajam, S. and Raghavan, S., 1983, "A Kinetic Study of Enargite Dissolution in Ammoniacal Solutions," International Journal Of Mineral Processing, Vol. 10, pp. 113-129.

Gow, R., Young, C., Huang, H., Hope, G., and Takasaki, Y., 2014a, "Spectroelectrochemistry of Enargite II: Reactivity in Acidic Solutions," Minerals and Metallurgical Processing.

Gow, R., Young, C., Huang, H. and Hope, G., 2014b, "Spectroelectrochemistry of Enargite III: Reactivity in Alkaline Sulfide Solutions," Minerals and Metallurgical Processing.

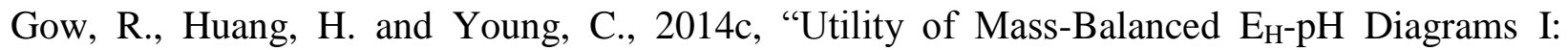
Application of Gibbs' Phase Rule," Minerals and Metallurgical Processing.

Gow, R., Huang, H. and Young, C., 2014d, "Utility of Mass-Balanced E $\mathrm{H}_{-} \mathrm{pH}$ Diagrams II: CuAs-S- $\mathrm{H}_{2} \mathrm{O}$ System," Minerals and Metallurgical Processing.

Haynes, W., 2011, CRC Handbook of Chemistry and Physics, 92nd Edition, CRC Press.

Helz, G. and Tossell, J., 2008, “Thermodynamic Model of Arsenic Speciation in Sulfidic Waters: A Novel Use of Ab Initio Computations," Geochemica et Cosmochimica Acta, Vol. 72, pp. 4457-4468.

Huang, H., 2012, “STABCAL,” Metallurgical \& Materials Engineering, Montana Tech.

Huang, H., Twidwell, L. and Young, C., 2005 "Speciation for Aqueous Systems - An Equilibrium Calculation Approach," Proceedings of COM 2005 \& 35th Annual Hydrometallurgical Meeting, Calgary, Canada.

Huang, H. and Young, C., 1986 "Modification of STABCAL for the Mass-Balanced Calculations of $\mathrm{E}_{\mathrm{H}-\mathrm{pH}} \mathrm{Diagrams,"} \mathrm{Electrochemistry} \mathrm{in} \mathrm{Mineral} \mathrm{and} \mathrm{Metal} \mathrm{Processing} \mathrm{IV,}$ Electrochemical Society, Pennington, NJ.

Koch, D. and McIntyre, R., 1976, "The Application of Reflectance Spectroscopy to a Study of the Anodic Oxidation of Cuprous Sulphide," Journal of Electroanalytical Chemistry, Vol. 71, pp 285-196.

Mathieu, H. and Rickert, H., 1972, "Electrochemical-thermodynamic studies on the CopperSulfur Systems at 15-90,"Zeitschrift fur Physikalishe Chemie, Vol. 79, pp 315-330.

Mihajlovic, I, Strbac, N., Zivkovic, Z., Kovacevic, R., and Stehernik, M., 2007, “A Potential Method for Arsenic Removal from Copper Concentrates,"Minerals Engineering, Vol. 20, pp. 2633.

Nishimura, T., Itoh, C. and Tozawa, K., 1993, "Equilibria of $\mathrm{Cu}(\mathrm{II})-\mathrm{As}(\mathrm{III}, \mathrm{V})-\mathrm{H}_{2} \mathrm{O}$ System at $25^{\circ} \mathrm{C}$," Bulletin of the Research Institute of Mineral Dressing and Metallurgy., Vol. 49, pp. 6170 . 
Padilla, R., Rivas, C. and Ruiz, M., 2008, "Kinetics of Pressure Dissolution of Enargite in Sulfate-Oxygen Media," Metallurgical and Materials Transactions B, Vol. 39B, pp. 399-407.

Potter, R., 1977, “An Electrochemical Investigation of the System Copper-Sulfur,” Economic Geology, Vol. 72, pp 1524-1512.

Robie, R., Hemingway, B. and Fisher, J., 1984, "Thermodynamic Properties of Minerals and Related Substances at 298.15K and 1 Bar (10 5 Pascals) Pressure and at Higher Temperatures," U.S. Geological Survey Bulletin 1452.

Tongamp, W., Takasaki Y. and Shibayama, A., 2010a, "Selective Leaching of Arsenic from Enargite in NaHS-NaOH Media, Hydrometallurgy, Vol. 101, pp. 64-68.

Tongamp, W., Takasaki Y. and Shibayama, A., 2010b "Precipitation of Arsenic as $\mathrm{Na}_{3} \mathrm{AsS}_{4}$ from $\mathrm{Cu}_{3} \mathrm{AsS}_{4}-\mathrm{NaHS}$ - NaO,H Leach Solutions,” Hydrometallurgy, Vol. 105, pp. 42-46.

Viñals, J., Roca, A. Hernandez M. and Benavente, O., 2003, "Topochemical Transformation of Enargite into Copper Oxide by Hypochlorite Leaching," Hydrometallurgy, Vol. 68, pp. 183-193.

Woods, R., Yoon, R. and Young, C., 1987, " $\mathrm{E}_{\mathrm{H}} \mathrm{pH}$ Diagrams for Stable and Metastable Phases in the Copper-Sulfur-Water System," International Journal of Mineral Processing, Vol. 20, pp. 109-120.

Young, C., Dahlgren, E. And Robins, R., 2002 'The Solubility of Copper Sulfides under Reducing Conditions," Hydrometallurgy, Vol. 68, pp. 23-31.

Young, C., Woods, R. and Yoon, R., 1988, “A Voltammetric Study of Chalcocite Oxidation to Metastable Copper Sulfides," Proceedings of International Symposium of Electrochemistry in Mineral and Metal Processing II, P. E. Richardson and R. Woods, eds., Electrochemical Society, Pennington, N.J., pp. 3-17. 